\title{
Report
}

\section{Changes of Agricultural Land Uses in Rural Area and Causes Behind It: A Case Study of Kamargaon Union Under Tanore Upazila in Rajshahi District}

\author{
Dulal Sarker $^{1,}$,, Md. Abdul Wakil ${ }^{2}$ \\ ${ }^{1}$ Department of Urban \& Regional Planning, Rajshahi University of Engineering \& Technology, Rajshahi, Bangladesh \\ ${ }^{2}$ Department of Urban \& Regional Planning, Bangladesh University of Engineering \& Technology, Dhaka, Bangladesh
}

Email address:

dulalsarker.ruet@gmail.com (D. Sarker),mawakil.wakil@gmail.com (Md. A. Wakil)

${ }^{*}$ Corresponding author

\section{To cite this article:}

Dulal Sarker, Md. Abdul Wakil. Changes of Agricultural Land Uses in Rural Area and Causes Behind It: A Case Study of Kamargaon Union Under Tanore Upazila in Rajshahi District. Urban and Regional Planning. Vol. 3, No. 1, 2018, pp. 20-26. doi: 10.11648/j.urp.20180301.14

Received: November 20, 2017; Accepted: January 12, 2018; Published: January 23, 2018

\begin{abstract}
Rajshahi District is a very high density of population and very high intensity of land use. In Rajshahi District per capita land is estimated to be only about 0.0526 ha. The Population growth rate is also high. For the high growth rate of population requires huge land for settlement and with the increase of population the demand of food also increases. For meeting the increasing food demand the land is using very intensively of this District. Every year the district is losing $0.47 \%$ arable land due to the population growth and its infrastructure development. This study was conducted on Tanore Upazila where the major focus was to see the changes of Rural Agricultural land uses and the causes of agricultural land use changes. For analyses both primary data and secondary data were collected. Primary data were collected by applying PRA techniques and secondary data were collected from published and unpublished data regarding crop, population and other sources. Results show that huge change in rural agricultural land uses take place in the study area and find some important causes of agricultural land use changes in rural area. Infrastructural development is the main causes of agricultural land losses. If proper steps would not be taken it creates great problems in near future.
\end{abstract}

Keywords: Agricultural Land, Changes, Causes, PRA

\section{Introduction}

\subsection{Background of the Study}

Rajshahi District (Zila), which covers an area of $2407 \mathrm{~km} 2$, of which $62 \mathrm{~km} 2$ is river, is located in the north west of Bangladesh bordering India to the south [1]. As almost 70\% people live in rural area and most of the people depend on agricultural activities. As a result there is a pressure on agricultural land. Almost 80 percent of the total population live in rural areas and of them $36 \%$ are below poverty line. There is limited employment opportunity in farming and urban manufacturing sector. Rajshahi District is one of the largest populated districts of Bangladesh but smallest one according to area. Rajshahi District is a newly industrial arena and the rate of population growth is very high (1.34\%). As its area is restricted so the basic requirements of the people have to maintain by the limited land area of the District. Hasty growth rate of population is responsible for rapid expansion of infrastructures. Fast growing rate of infrastructures causes of losses of agricultural land. Every year almost one percent of its arable land loses in this District [2]. In our study area Kamargaon union, we have found that there is a huge amount of land use change in recent years and increase the intensity of use of agricultural land. The study was to see the amount of land use changes that were actually use for agricultural purposes in rural area in recent past year. The study was to see the changes of agricultural land use in rural area in recent past years. The study is useful to know the percentages of land that are use for various purposes. The survey is conducted in rural 
area and it is also helpful to find out the changing pattern of the rural Agricultural land uses. Rajshahi District has been passing through a process of urbanization and population growth since the last few decades. Rapid growth of population, unplanned urbanization, industrialization and agricultural modernization in the outer periphery area of this district city has created pressure on the agricultural land. This research is helpful to find out the causes of changing of agricultural land use.

\subsection{Study Area Profile}

Kamargaon Union under Tanore Upazila in Rajshahi District (Figure 1) is selected as a study area for the study. The Average literacy rate of tanore upazila is $45.4 \%$ of them male $50.1 \%$ and female $40.6 \%$. In this upazila, there are number of Educational institutions which are college 18, secondary school 62, primary school 122, NGO School 57, madrasa 13. In this upazila, there are many Religious institutions which are Mosque 478, temple 25, church 20, sacred place 1. Noted religious institutions: Gollapara Jami Mosque, Kamargaon Jami Mosque, Dhalia and Bhagna Jami Mosque, Pir Tomb at village Sidhair, Pagla Shah Dargah at Madaripur Hat, Kamargaon Shiva Mandir, Shiva Mandir at Shivatala, Mandir and Math at Tanore, Mundumala Mandir and Church at
Mahali Para. In this upazila, there are number of Cultural organizations Library 10 , club 30 , cinema hall 2, theatre stage 1 , women society 70 , playground 4 . In the study area, main sources of income Agriculture $78.35 \%$, non-agricultural laborer 2.53\%, commerce $7.66 \%$, transport and communication $1.58 \%$, service $3.22 \%$, construction $0.37 \%$, religious service $0.14 \%$, rent and remittance $0.11 \%$ and others $6.04 \%$. $51.37 \%$ of people have their own land and $66.27 \%$ of people are landless. Agricultural landowner: urban owner $48.80 \%$ and rural owner 51.95\%. Main crops Paddy, wheat, jute, betel leaf, potato, mustard, masur, kalai, vegetables. Communication facilities: Pucca road $250 \mathrm{~km}$, semi-pucca road $102 \mathrm{~km}$, mud road $1132 \mathrm{~km}$; railway $1 \mathrm{~km}$; waterway 2.67' nautical miles. Hats, bazars and fairs Hats and bazars are 15, fairs 5, most noted of which are Mundumala Hat, Kamargaon Hat, Talanda Hat, Kalma Hat, Kaliganj Hat, Gollapara Hat, Flower Mela at Mundumala, Billi Mela, Chaitra Sankranti Mela at Kamargaon, Muharram Mela at Madirpur, Kalipujar Mela and Ayra Durga Pujar Mela. Health centres Upazila health centre 1, family planning centre 9, clinic 1 [3]. Tanore Upazila (rajshahi district) area $295.39 \mathrm{sq}$ $\mathrm{km}$, located in between $24^{\circ} 29^{\prime}$ and $24^{\circ} 43^{\prime}$ north latitudes and in between $88^{\circ} 24^{\prime}$ and $88^{\circ} 38^{\prime}$ east longitudes (Figure 1) [3].

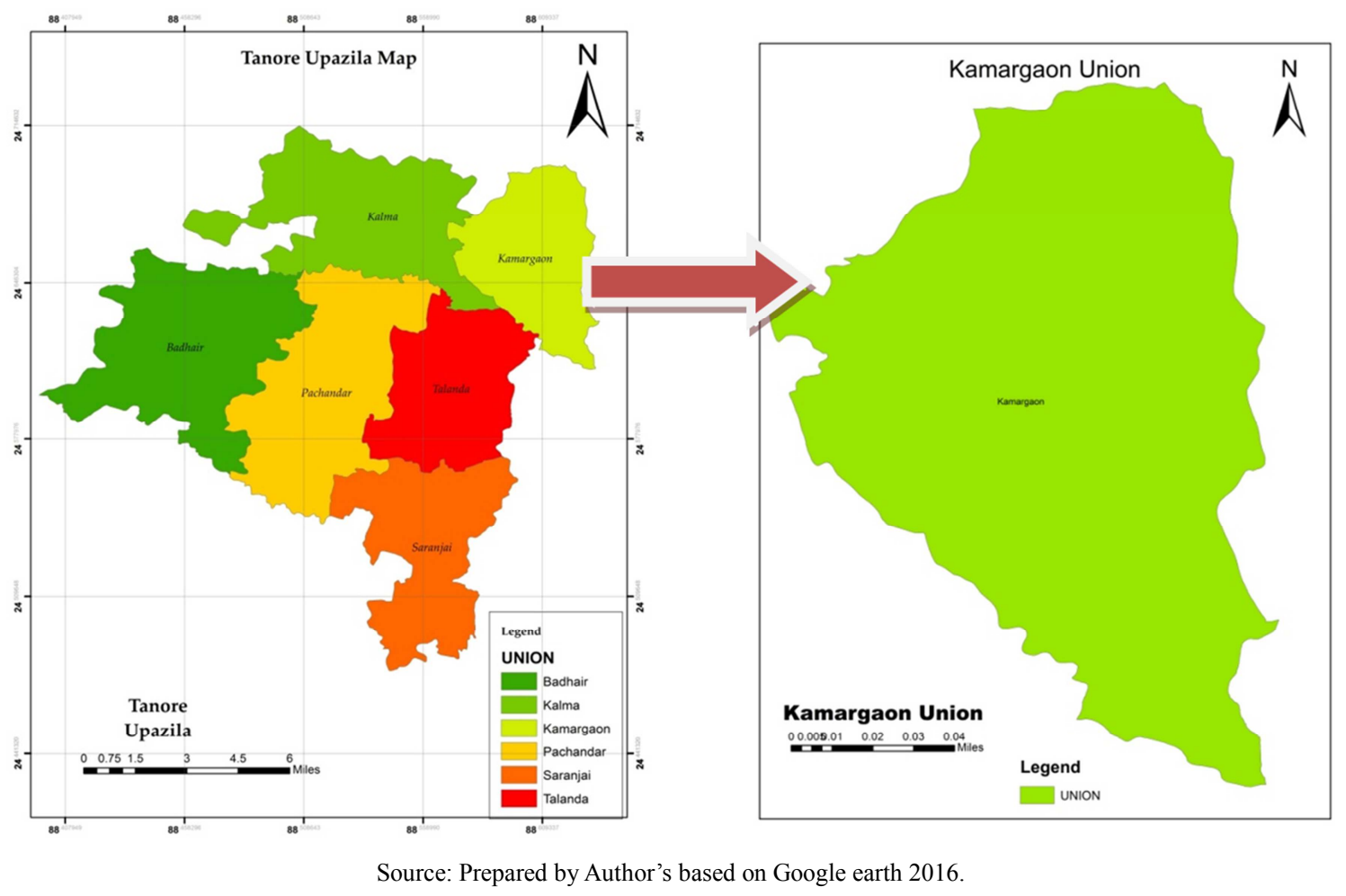

Figure 1. Study area map.

\section{Methods}

The principal objective of this study is to find out the changes of rural agricultural land use and the causes of change of agricultural land use in rural area. Specially increase the built up area, mango orchads, and ponds and so on at
Kamargaon union area under Tanore Upazila in Rajshahi district. For doing this, several methods has been applied. The changes and causes of rural agricultural land are shown by participatory rural appraisal (PRA) method. The major goal of this study is to find out the changes and causes of rural agricultural land uses. Based on the availability of data, the primary and secondary both type data used in this study. The 
primary data have been collected through PRA method and the secondary data have been collected from the most the government census data and non-government Published and unpublished data. This information's are mostly collected by the field survey and analyzed by using various statistical techniques.

\section{Results}

\subsection{Changes of Land Use}

In the Figure 2, we found that in the last 10 years the land use of Nizampur village under Kamargaon union area has changed significantly.

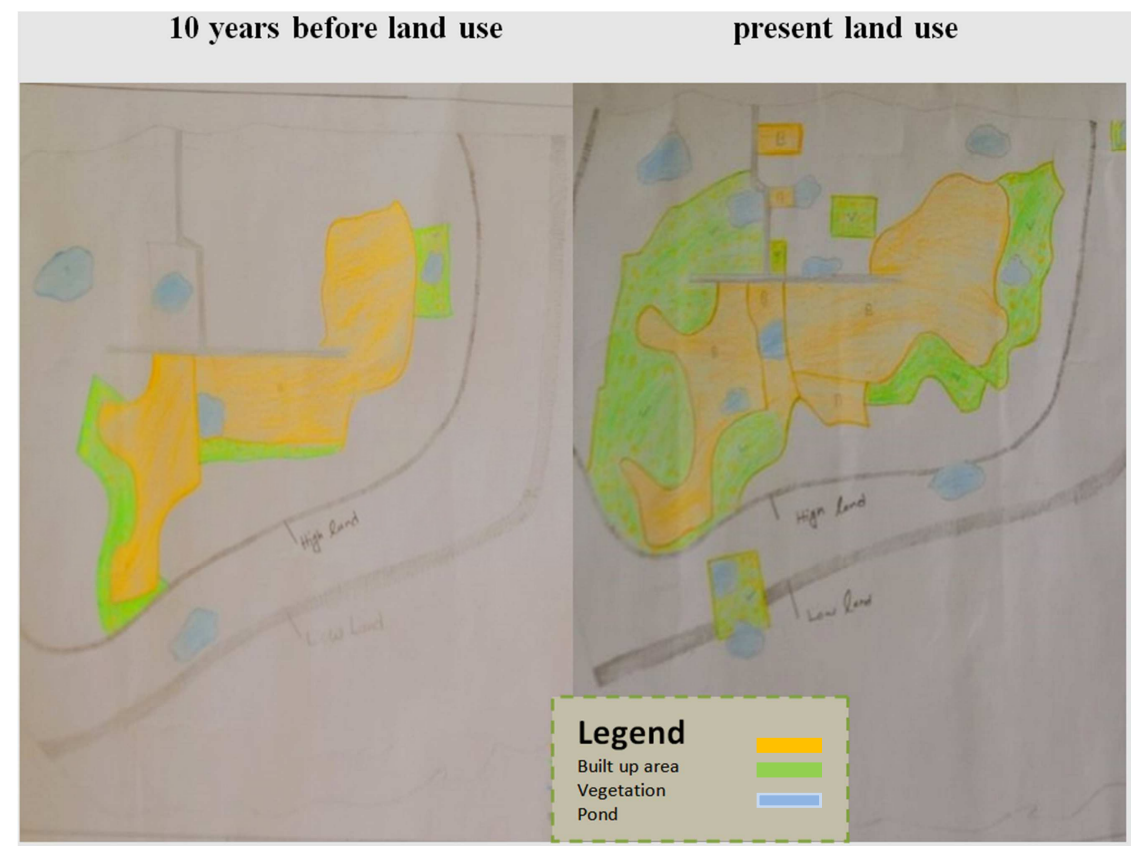

Source: Participatory Rural Appraisal (PRA), 2016.

Figure 2. Rural Land use map.

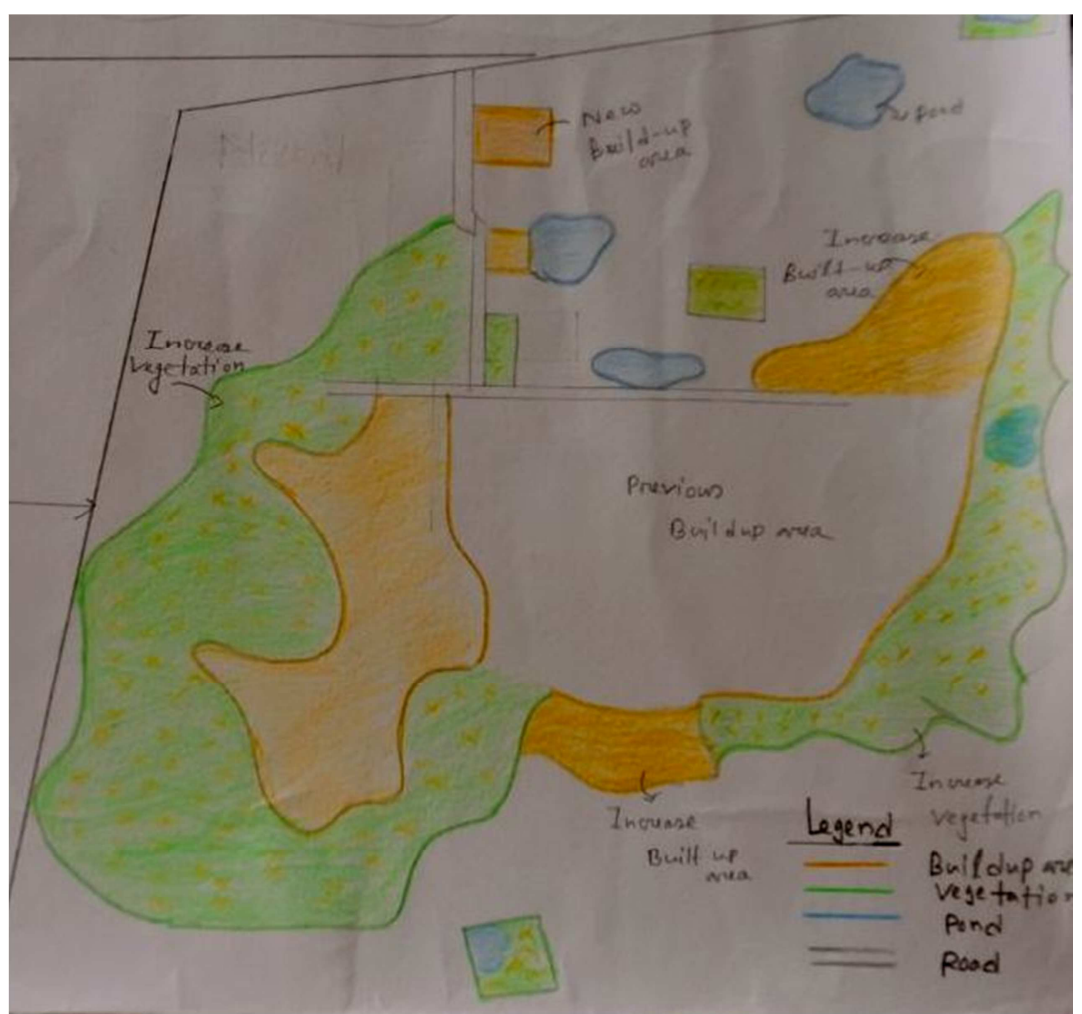

Source: PRA, 2016.

Figure 3. Rural Land use change map. 
Of them built up, forest and ponds area have been increased in a good rate. In recent years, people prefer to use their agriculture land for digging ponds and making forest (Figure 3).

\subsection{Causes of Rural Agricultural Land Use Changes}

For the causes analysis Participatory Rural Appraisal (PRA) method had been applied. From the experience of local people they discussed about the causes of rural agricultural land use changes which are given below:

\subsubsection{Changes of Settlement Area}

In Kamargaon union, Population growth is the main cause of rural agricultural land losses. For the increased in population, people have to build houses for their shelter so the amount of settlement has increased. By the PRA survey, a new thing comes out as a cause of agricultural land losses is also the family problem. The PRA member mention that with the expanded of family, the problem among the family members creates and they divided their family into nuclear individual family. After separation the built new houses and in the rural area there is a tradition that more new settlement grows around the new houses and creates a haphazard settlement of the area. It's became a causes of agricultural land losses. Road is another type of infrastructure that is one of the most important cases for agricultural land losses. The Population growth is presented in figure 4.

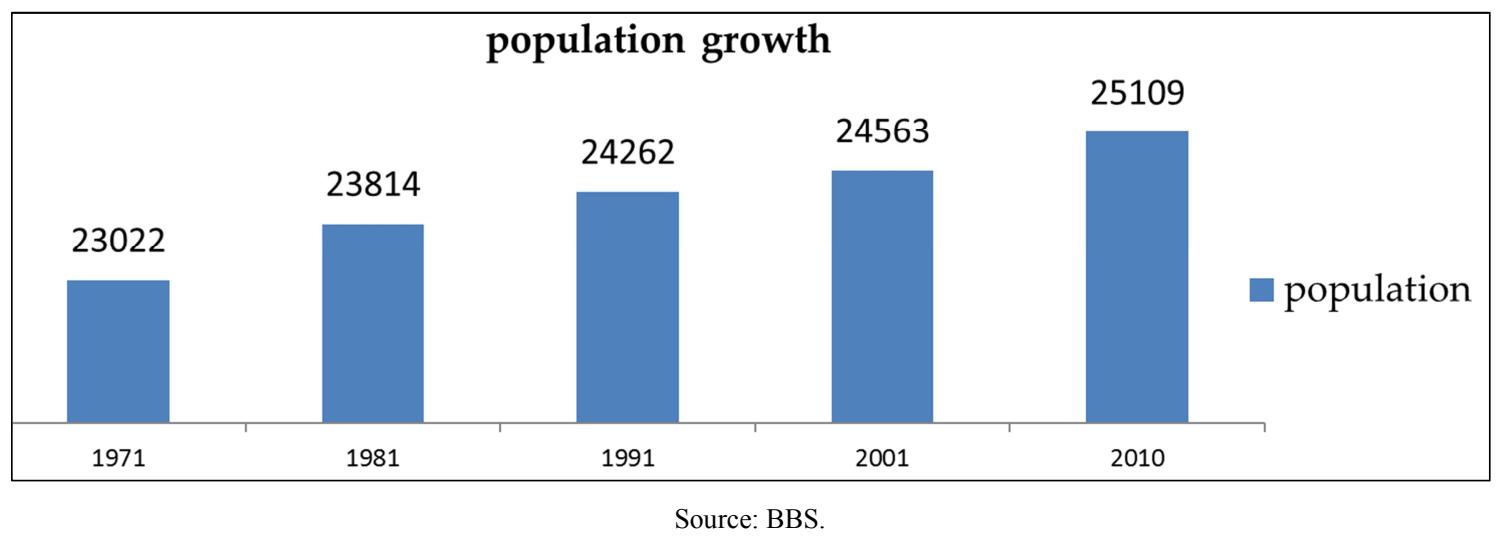

Figure 4. Population growth.

The economic condition of rural area is growing up better day by day. The profession is changing there are a lot of people working abroad and earns a great amount of foreign currency. For the economic growth people spent their money for better living and building up expensive house in agricultural land. This is the one of cause of agricultural land losses.

\subsubsection{Increases Educational Institutions}

In Kamargaon union, there are a lot of number educational institutions in Rajshahi district (Figure 5). With the time it's growing more and more. For this institutional infrastructure development the agricultural land is losing day by day.

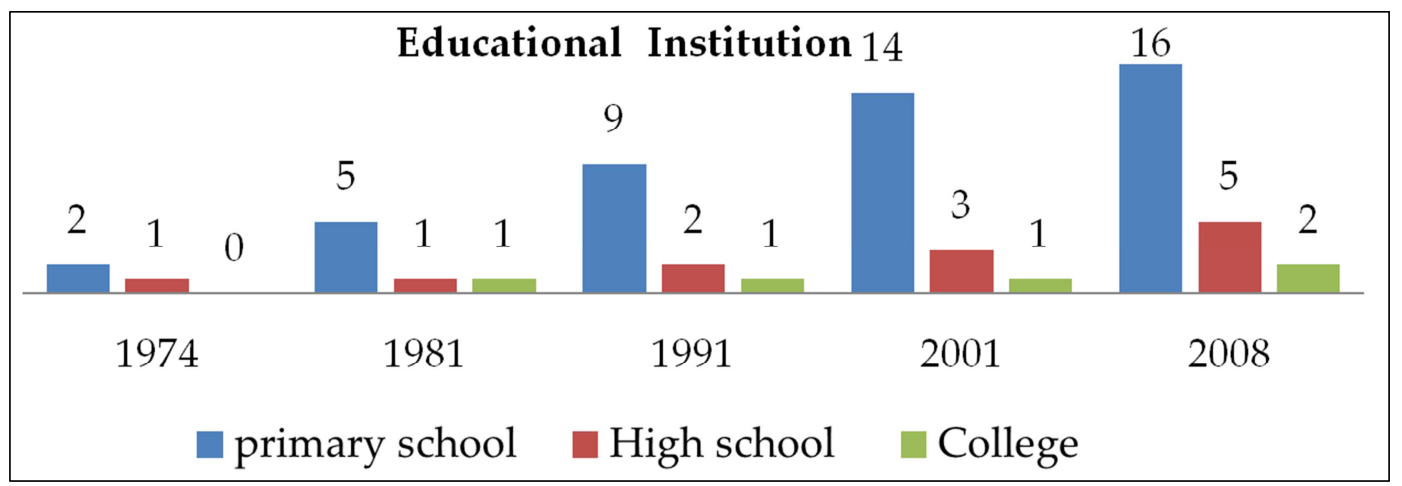

Source: BBS.

Figure 5. Educational institutions.

\subsubsection{Increases Socio-Economic Institutions}

In Kamargaon union, the infrastructure development for Socio-economic institution is the most important causes of losing agricultural land. Socio-economic institution is itself is a consumer of agriculture land and it's helps people to build up infrastructure. The number Socio-economic institution increases (Figure 6). 


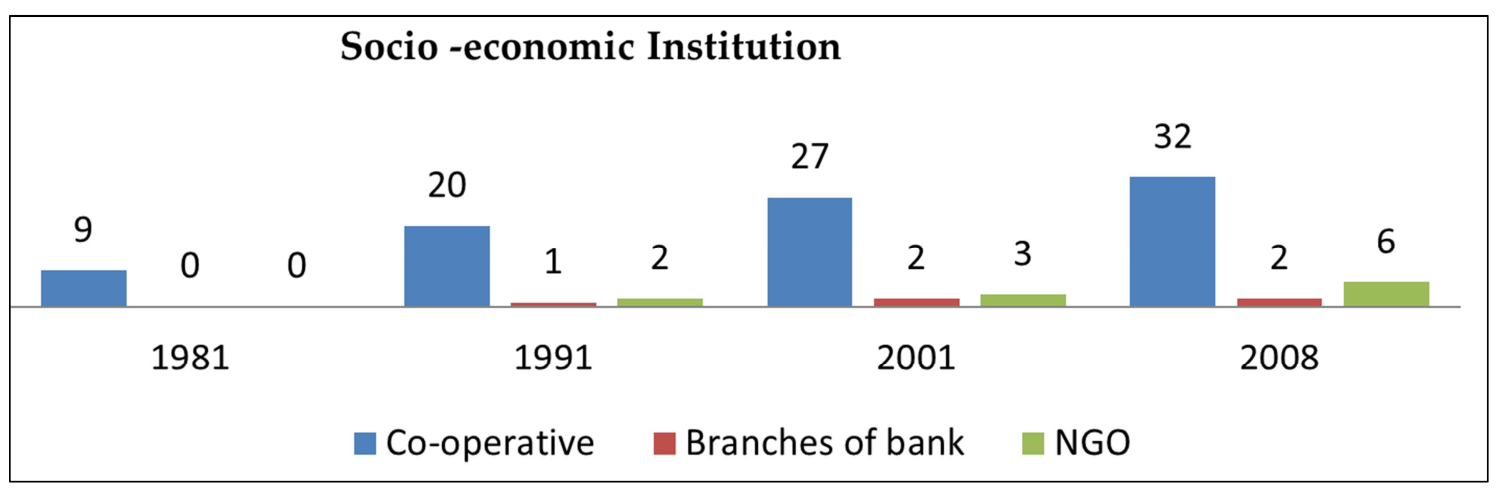

Source: BBS.

Figure 6. Socio-economic institutions.

\subsubsection{Changes of Forest Area}

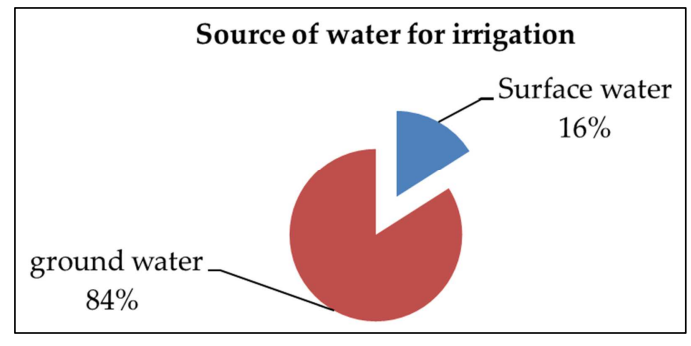

Source: Field survey.

Figure 7. Source of water for irrigation.

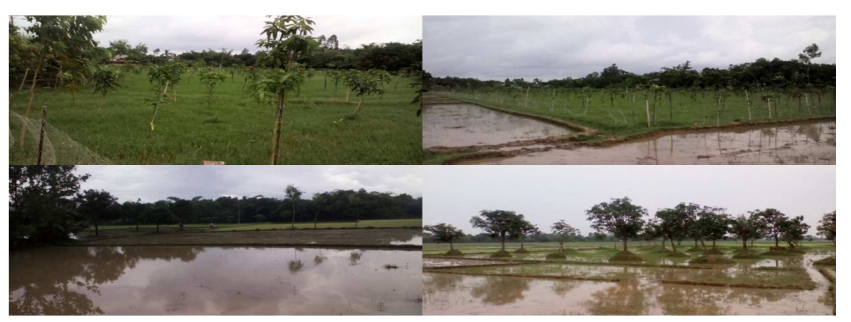

Source: Field Survey, 2016

Figure 8. New orchards.

Orchard is one of the main causes of agricultural land losses. Day by day orchards are increasing in rural area. Especially Mangoes, Lichi, Kul and other type of Orchard are growing up and grain food crops are decreasing. In the rural area, the amount of forest land has increased in recent years. People in rural area has increased the practice of forest because of the rate of return from agriculture is very low. In the rural areas there is a shortage of labor in recent years due to migration in town or change their occupations. The rate of return from the forest like mango orchards is higher than the agriculture. In the low or middle land people can cultivate two or three times so they prefer making forest in the high land. Because of increased population the land fragmentation has increased and creates too many small plots of land. In these small plots people prefer to make orchard. In the high land the irrigation system is very bad and very expensive. In summer season there is a scarcity of water for irrigation of land. Mainly ground water is used for the irrigation of these lands (Figure 7).

The numbers of many new orchards are increasing in every year on agriculture land (Figure 8).

\subsubsection{Changes Area of Water Body}

In the rural area create a tread that people are more emphasis on digging ponds in their agricultural land. There are some causes: The rate of return from pond is much more than agriculture. For the cultivation there is a shortage of labor force in recent years. There is certainty that they get profit.

\section{Discussion}

\subsection{Occupation Changes}

According to PRA, There has significant changed in the occupational pattern in the study area. In the study area, most of the household head's main occupations were agriculture. Later some of the farmers have changed their principle occupation to other occupation. So besides agriculture, people frequently are engaged in handicraft, transport, fishing and other services. In these area livestock keeping is also one major economic activity of the households. This is mainly practiced by the women of the households. Trade includes wholesale business of rice, pulses and other crops.

\subsection{Size Distribution of Farm Holdings}

The average holding plot size is declining over time due to a decline in land availability per capita and the tendency towards the splitting up of existing holdings (Figure 9). There was a general decline reflected among small, medium, and large farms. The small farm proportions are increasing in number. Small farms and plots pose obvious problems of scale including difficulty in applying machine-based techniques, loss of land for boundaries and management of scattered plots. 


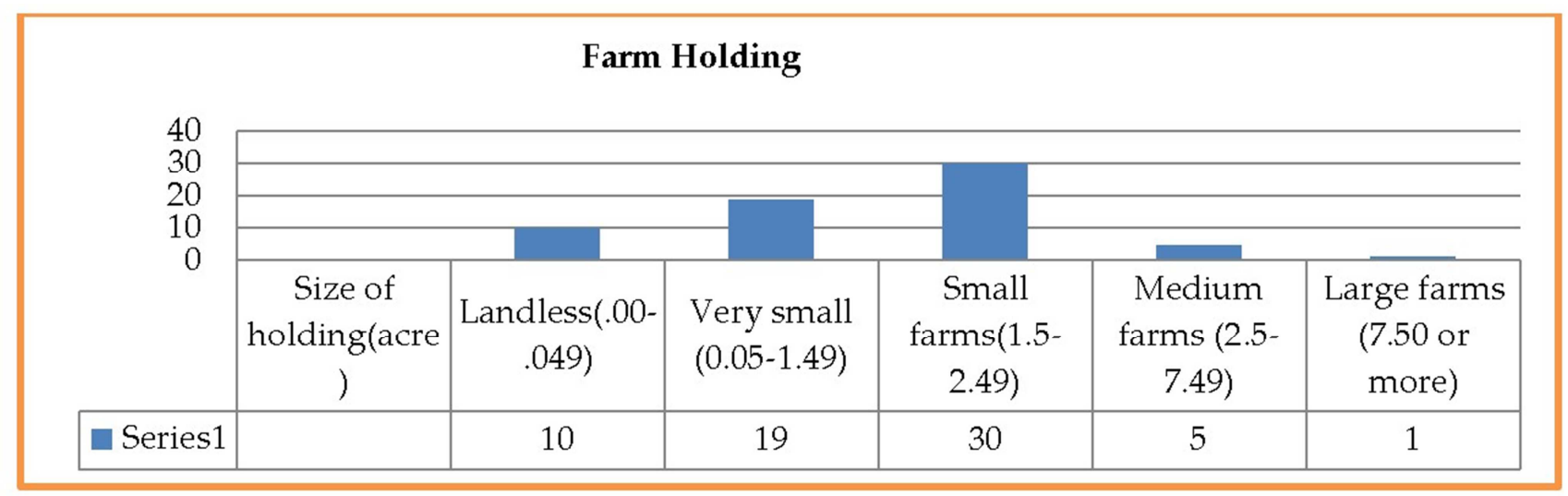

Source: Field survey 2016.

Figure 9. Farm Holdings.

\subsection{Landlessness}

With the increase of population growth trends the rate of landlessness rises. At present 9 percent of households own no land what so ever, neither homestead nor arable land. By adding those who own homesteads but no arable land, the proportion of landlessness rises to 28 percent.

\subsection{Cropping Intensity}

Cropping intensity has increased. As a result of the influence of declining holding plot sizes increase cropping intensity in rural agricultural land (Figure 10). Cropping intensity is constrained by lack of irrigation in the dry season. Middle land are suitable for cultivate three times in a year.

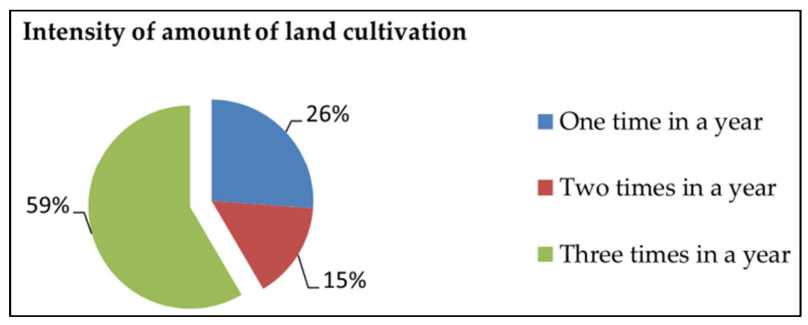

Source: Field survey 2016.

Figure 10. Cropping intensity.

\subsection{Economic Activities}

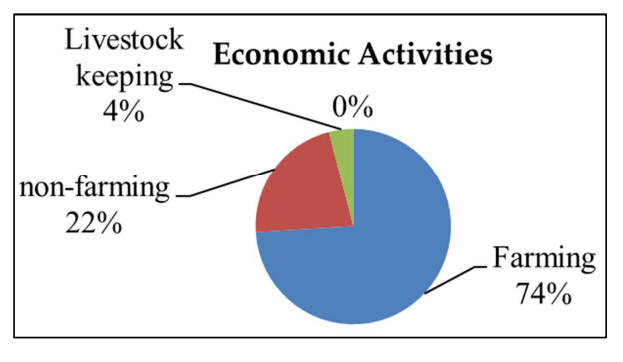

Source: Field survey 2016.

Figure 11. Economic activities.

Major economic activity of the study area includes various economic activities like crop farming, livestock keeping, various non-farm activities etc. it is found that the majority of households are engaged in farm activities (74\%). According to PRA, It also shows that non-farm activities are engaged by $22 \%$ households which have increased over time period. Only $4 \%$ of responses indicated that households practice livestock keeping (Figure 11).

\section{Conclusion}

Agricultural systems are dynamic in the sense that they are in a continual state of Change. Agriculture is practiced in the form of production systems, enterprises, or farming systems. Their economic viability generally is an important evaluation criterion, although it is not the only one. The methods of production to be used, the type of infrastructure, and the extension services required. With unchecked population growth and economic development in the study area, infrastructural land has increasingly expanded and encroached upon agricultural land in the last few years. In this paper analyzes the changes of agricultural land use and causes for agricultural land use change in rural area. By using primary and secondary data integrated, it was found that agricultural land use has changed over the time period. Because of agricultural land use changes it creates pressure on food security and environment. The food production decreasing, food price rising and land fertility decreasing and this all are the result of agricultural land use changes and losses of agricultural land. Infrastructural development is the main causes of agricultural land losses.

\section{References}

[1] BBS (Bangladesh Bureau of Statistics) 2002. Bangladesh Population Census, 2001. Ministry of Planning, Dhaka. Govt. of Bangladesh.

[2] Isalm, M. R. (2013). Causes and consequences of Agricultural land losses of Rajshahi District, Bangladesh. IOSR Journal of Environmental Science, Toxicology And Food Technology (IOSR-JESTFT), 5 (6), 58-65. 
[3] Banglapedia 2014. National Encyclopedia of Bangladesh. Asiatic Society of Bangladesh. Genesis Printing and Packaging, Dhaka.

[4] BBS (Bangladesh Bureau of Statistics) 2011. Census of Agriculture, 2011. Zilla Series, Rajshahi. Bangladesh.
[5] BBS (Bangladesh Bureau of Statistics) 2010. Statistical Yearbook of Bangladesh. Ministry of Planning, Dhaka.

[6] BBS (Bangladesh Bureau of Statistics) 2013. Statistical Yearbook of Bangladesh. Ministry of Planning, Dhaka. Govt. of Bangladesh. 